\title{
Distribution of hepatitis B virus genotypes in Europe and clinical implications: a review
}

\author{
Nina Kmet Lunaček ${ }^{1 凶}$, Mario Poljak², Mojca Matičičč,
}

\begin{abstract}
With an estimated 15 million infected persons in Europe, hepatitis B virus (HBV) infection is still one of the leading causes of chronic liver disease and associated mortality. The HBV infection prevalence in the general population depends on the region and ranges from $0.01 \%$ in Scandinavia to $10.3 \%$ in Kyrgyzstan. The prevalence of the 10 HBV genotypes (A-J) varies among different parts of the world, with genotypes $A$ and $D$ being most prevalent in Europe. Other HBV genotypes are mainly imported into Europe from other parts of the world and are rarely detected. HBV genotypes influence the clinical outcome of HBV infection, HBeAg seroconversion rates, and the frequency of mutations in the pre-core and core promoter regions. In addition, response rates to treatment with pegylated interferon alpha vary among HBV genotypes, whereas there is no influence of HBV genotypes on treatment response when using nucleoside/nucleotide analogues. Due to recent large-scale immigration to Europe, a change in HBV genotype distribution and the consequent clinical outcome of chronic hepatitis B may be expected in the near future.
\end{abstract}

Keywords: hepatitis B virus, genotypes, distribution, Europe, clinical implications, antiviral therapy

Received: 17 March 2018 | Returned for modification: 18 April 2018 | Accepted: 26 June 2018

\section{Introduction}

The hepatitis B virus (HBV) is a small DNA virus belonging to the Hepadnaviridae family, genus Orthohepadnavirus. In humans HBV infection results in either an acute, self-limiting disease, or a long-term infection that remains unresolved and persistent (1). Due to complications such as end-stage liver disease and primary hepatocellular carcinoma (HCC), chronic HBV infection globally represents the leading cause of chronic liver disease and associated mortality (2). With an estimated 257 million infected people worldwide, HBV infection presents a global public health problem despite the long-term existence of a highly effective hepatitis $B$ prevention vaccine and relatively effective treatment of chronic hepatitis B (CHB) (3). The prevalence of HBV infection in the general population depends on the region and ranges from $0.01 \%$ in northern European countries to $22.3 \%$ in the Pacific region (3-5). In Europe, the average HBV prevalence has been estimated at $1.5 \%$, with 15 million people infected (3).

HBV has been classified into 10 different genotypes (A-J), according to the difference in overall genomic sequences (presenting more than an $8 \%$ difference) or in sequences of gene coding surface antigen (HBsAg, presenting more than a $4 \%$ difference) (6). The prevalence of HBV genotypes varies among different parts of the world: genotype A is mainly found in northern Europe, North America, India, and Africa; genotypes $\mathrm{B}$ and $\mathrm{C}$ are most prevalent in southeast Asia; and genotype D is most prevalent in southern Europe, the Middle East, and India $(7,8)$. In Europe, genotypes A and $\mathrm{D}$ were found to be most prevalent (9).

HBV genotypes influence clinical outcomes of hepatitis B, clinical course, progression of the disease, chronicity, risk of HCC, mutations in the pre-core and core promoter regions, seroconversion rates of $\mathrm{HBV}$ e antigen (HBeAg), and response to antiviral therapy $(7,8)$.

\section{Overview and geographical distribution of HBV genotypes and subtypes}

In recent years, several European and Mediterranean countries have reported on the prevalence of HBV genotypes, showing a clear geographical shift with genotype D being predominant in southeast Europe and Russia, and genotype A being most frequent in western countries and in Scandinavia (Table 1, Fig. 1) (10-30).

\section{Genotype A}

Genotype A is further divided in subtypes A1-A4. Subtypes A1, $\mathrm{A}_{3}$, and A4 are mainly found in Africa, whereas A2 prevails in northern and central Europe and in North America (8).

\section{Genotype D}

There are nine known subtypes of HBV genotype D (31). HBV subtype D1 is predominant in the Middle East and North Africa, subtype D2 has been found in Albania, Turkey, Brazil, western India, Lebanon, and Serbia, and subtype D3 in Serbia, western India, and Indonesia, especially in people who inject drugs (PWID). Subtype D4 has been rare and has been reported from Haiti, Russia, the Baltic countries, Brazil, Kenya, Morocco, and Rwanda. Subtype D5 is common in eastern India, subtype D6 in Indonesia, Kenya, Russia, and the Baltic region, and subtype $\mathrm{D}_{7}$ in Morocco and Tunisia. Subtypes D8 and D9 have recently been discovered and reported from Niger and India (31).

\section{Other genotypes}

Traditionally, HBV genotypes other than A and D were present in 
Europe sporadically, with most cases being imported to Europe either as a consequence of immigration from the Middle East, Asia, and Africa in past decades, or imported by European travelers that were infected abroad. Surprisingly, recent European studies reported a prevalence of up to $41 \%$ of non-A-D genotypes in the Netherlands, 28\% in France, and 26\% in Switzerland (14, 21, 27). In contrast, the genotype distribution in central European countries is still limited to genotypes $\mathrm{A}$ and $\mathrm{D}$, and the proportion of non-A-D genotypes has not exceeded 10\% (12).

\section{Co-infection with different HBV genotypes}

Mixed genotypes are possible co-infections with two distinct HBV genotypes (32). Sanger sequencing is the gold standard for genotype detection, but has lower sensitivity than other methods for detecting mixed genotypes because it mainly detects the predominant genotype in genotype mixtures $(33,34)$. Consequently, where sequencing is routinely used, the prevalence of mixed genotypes might be underestimated. According to reports from Europe, some

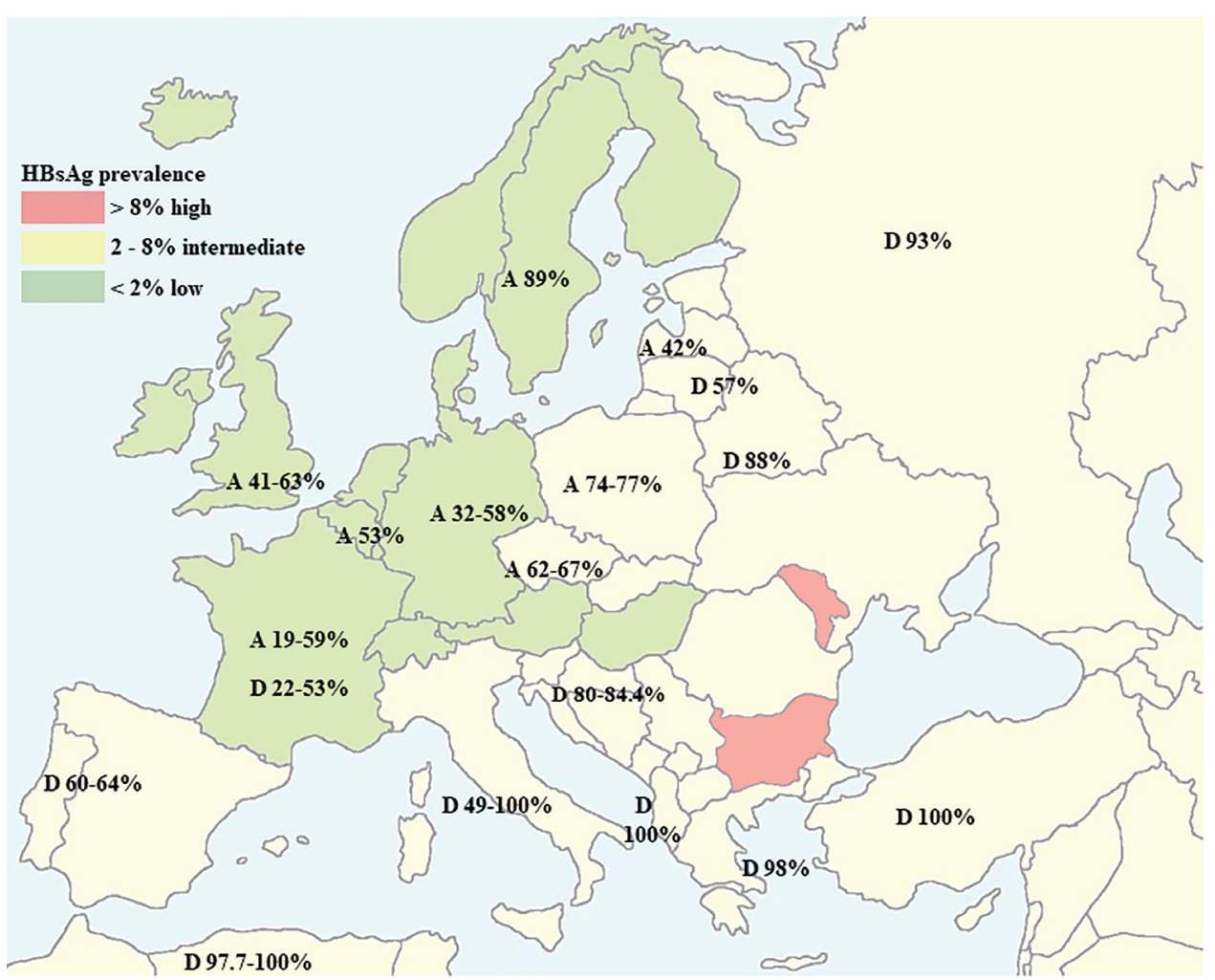

Figure 1 | Hepatitis B virus genotype distribution among European countries (8, 12-16, 18-20, 23-26, 28, 31).

Table 1 | Hepatitis B virus genotype distribution in selected Euro-Mediterranean countries (10-30).

\begin{tabular}{|c|c|c|c|c|}
\hline \multirow{2}{*}{ Study (country, author, year) } & \multirow{2}{*}{ Patients $(n)$} & \multicolumn{3}{|c|}{ Genotype [subtype] (\%) } \\
\hline & & A & D & Other \\
\hline Albania, Zehender et al., 2012 & 73 & & $\mathrm{D}(100 \%)$ & \\
\hline Bulgaria, Ciccozzi et al., 2013 & 15 & $A[2](28 \%)$ & $\mathrm{D}[1-3](72 \%)$ & \\
\hline Croatia, Deterding et al., 2008 & 100 & $A(8 \%)$ & $\mathrm{D}(80 \%)$ & $(12 \%)$ \\
\hline Czech Republic, Deterding et al., 2008 & 209 & $A(67 \%)$ & $\mathrm{D}(28 \%)$ & $(5 \%)$ \\
\hline France, Thibault et al., 2013 & 147 & $A(59 \%)$ & $\mathrm{D}(22 \%)$ & $(19 \%)$ \\
\hline France, Moussa et al., 2016 & 43 & $A(19 \%)$ & D (53\%) & $(28 \%)$ \\
\hline Germany, Deterding et al., 2008 & 133 & $A(32 \%)$ & $\mathrm{D}(58 \%)$ & $(10 \%)$ \\
\hline Greece, Fylaktou et al., 2011 & 135 & $A(1 \%)$ & D $(98 \%)$ & $(1 \%)$ \\
\hline Hungary, Deterding et al., 2008 & 255 & $A(47 \%)$ & D (43\%) & $(10 \%)$ \\
\hline Iran, Mojiri et al., 2008 & 89 & & D (100\%) & \\
\hline Italy, Zuccaro et al., 2015 & 100 & $A(45 \%)$ & $D(49 \%)$ & $(6 \%)$ \\
\hline Lithuania, Deterding et al., 2008 & 63 & $A(41 \%)$ & D $(54 \%)$ & $(5 \%)$ \\
\hline Montenegro, Vratnica et al., 2015 & 136 & $\mathrm{~A}[2](19.8 \%)$ & $\mathrm{D}[1-3](80.2 \%)$ & \\
\hline Morocco, Ezzikouri et al., 2008 & 91 & & D (100\%) & \\
\hline Netherlands, Toy et al., 2008 & 464 & $A(20-35 \%)$ & D (37-40\%) & $(28-41 \%)$ \\
\hline Poland, Deterding et al., 2008 & 248 & $A(77 \%)$ & D $(19 \%)$ & $(4 \%)$ \\
\hline Poland, Bissinger et al., 2015 & 276 & $A(19.9 \%)$ & D (68.1\%) & $(12 \%)$ \\
\hline Portugal, Mota et al., 2010 & 358 & $A(31 \%)$ & $\mathrm{D}(60 \%)$ & $(9 \%)$ \\
\hline Romania, Deterding et al., 2008 & 245 & $A(6 \%)$ & D $(67 \%)$ & $(27 \%)$ \\
\hline Russia, Deterding et al., 2008 & 60 & $A(6.7 \%)$ & D (93\%) & $(0.3 \%)$ \\
\hline Serbia, Lazarević et al., 2007 & 89 & $A(18 \%)$ & $\mathrm{D}(82 \%)$ & \\
\hline Serbia, Milosević et al., 2013 & 162 & $A(14.2 \%)$ & $\mathrm{D}(85.8 \%)$ & \\
\hline Slovenia, Kmet Lunaček et al., 2017 & 186 & $A(12.4 \%)$ & D (84.4\%) & $(3.2 \%)$ \\
\hline Switzerland, Hirzel et al., 2015 & 465 & $A(15.9 \%)$ & D (58.3\%) & $(25.8 \%)$ \\
\hline Tunisia, Yacoubi et al., 2015 & 1,615 & $\mathrm{~A}[2](2.3 \%)$ & $\mathrm{D}[1+7](97.7 \%)$ & \\
\hline Turkey, Sunbul et al., 2005 & 88 & & D (100\%) & \\
\hline Turkey, Ciftci et al., 2012 & 63 & & $\mathrm{D}(100 \%)$ & \\
\hline UK, Sloan et al., 2009 & 160 & $A(1+2)(63 \%)$ & $\mathrm{D}[1-4](25 \%)$ & $(15 \%)$ \\
\hline
\end{tabular}


HBV genotype A-infected persons had been successfully treated with PegIFN before later being diagnosed with genotype D rebound infection (35).

Some early reports have shown that a substantial fraction of chronically infected persons in central Europe, especially from the southeastern region, are infected with mixed HBV genotypes, ranging from $0.8 \%$ in Germany to $27 \%$ in Romania $(9,12)$. At least some of the mixed infections detected were probably false positives due to the use of genotyping tests that lacked specificity for certain HBV genotypes.

\section{Epidemiology of HBV genotypes in Europe}

Reports from different parts of Europe show that those with sexrelated risk factors for acquiring HBV infection, especially men having sex with men (MSM), are more frequently infected with HBV genotype A. A Dutch study reported an ongoing outbreak among MSM in Amsterdam caused by a single HBV genotype A strain (36). Similarly, in the UK, HBV genotype A is more prevalent in MSM compared to other risk groups (15). A recent study from Slovenia also showed that MSM have been more often infected with genotype A than genotype D (26).

A report from several central European countries suggested that, compared to genotype D, genotype A was more often found in older patients, whereas genotype D predominated in younger ones (22). This observation might be a consequence of changing sexual and travel behaviors of the population (37), as well as the change in modes of HBV transmission. Globally, increased awareness of sexually transmitted infections (STIs) has led to more common use of prevention measures; however, the highly increased frequency of traveling, particularly to endemic areas for STIs, significantly influences the importation of STIs, including HBV infection to Europe (37). In recent decades, due to implementation of HBsAg screening for pregnant women in many European countries, mother-to-child transmission in this part of the world has mostly been limited to children born to immigrant mothers and those with a history of family migration, particularly from the Balkan region, the Middle East, and North Africa, where genotype D prevails (10-12, 17, 19, 20, 24-26, 28-30, 38, 39).

Epidemiological data from the literature suggest that central Europe is on its way to switching from the previously predominant genotype A to predominance of genotype D (22). Recently, Bissinger et al. showed that in central European countries the number of observed age-related genotype A-infected persons decreased from a high level $(71.4 \%)$ to average $(20 \%)$, whereas in countries outside of central European only small variations in the proportion of genotype A were noticed, remaining at low rates of around $10 \%(22)$. One of the reasons for this significant shift may be related to the ongoing global migration flow (22) due to the current geopolitical situation. Recent studies from two German regions with high proportions of immigrants from the Mediterranean area have reported genotype D infection in $40 \%$ and $58 \%$ of infected persons, respectively (12). Similarly, Moussa et al. reported a 53\% prevalence of HBV genotype D in Marseille (14), and Hirzel reported a $58 \%$ prevalence of the same genotype in Switzerland (27).

\section{Clinical implications of HBV genotypes}

Studies have shown that HBV genotypes influence the clinical outcome of HBV infection as well as the response to antiviral therapy (Tables 2-3). Up until now, no systematic review or meta-analyses have been published comparing the clinical implications of all known HBV genotypes.

Studies from Asia report that the rate of spontaneous $\mathrm{HBeAg}$ seroconversion is higher in HBV genotype B-infected persons compared to those infected with genotype $\mathrm{C}(40-42)$. In the population from Alaska, compared to those infected with genotypes A, $\mathrm{B}, \mathrm{D}$ and $\mathrm{F}, \mathrm{HBeAg}$ seroconversion was less commonly achieved in HBV genotype $\mathrm{C}$-infected persons; genotypes $\mathrm{C}$ and $\mathrm{F}$ were associated with the highest rates of HBeAg reversion (43).

Sánchez-Tapias et al. reported that the HBeAg seroconversion rate was quite comparable between genotype $\mathrm{A}$ - and $\mathrm{D}$-infected persons; however spontaneous HBsAg seroconversion and biochemical remission were seen more often in persons infected with genotype A than with genotype D (44).

Among all HBV genotypes, HBeAg-negativity was most often seen in HBV genotype D-infected persons $(45,46)$. Compared to genotype A, HBeAg-negativity was more common in genotypes $\mathrm{B}$ and $\mathrm{D}$, whereas it was found to be more common in genotype $\mathrm{B}$ than in genotype $C$ (47).

Compared to HBV genotypes $\mathrm{C}$ and $\mathrm{D}$, genotype $\mathrm{A}$ is most likely to progress to chronic HBV infection (48-50).

Studies in children showed higher HBV DNA viral loads in those infected with genotype $\mathrm{D}$ in comparison to those with genotype A (51). Lindh et al. showed that the viral loads in genotype D-infected HBeAg-positive patients were higher compared to the viral loads in those infected with other HBV genotypes (52). Other studies performed in either adult or pediatric populations showed no differences in viral loads among patients infected with various HBV genotypes $(26,53,54)$.

Table 2 | Summary of potential implication of hepatitis B virus genotypes on clinical course of chronic hepatitis B virus infection (compiled from 26, 47-60, 62-68).

\begin{tabular}{ll}
\hline Clinical outcome & HBV genotypes \\
\hline HBeAg-seroconversion & C less likely than A, B, D, and F; \\
& D less likely than A \\
HBeAg seroclearens & D less likely than A \\
HBsAg-negativity & B less likely than C; \\
& D most likely; \\
& A less likely than B and D \\
Chronicity & C and D less likely than A \\
Viral load & A lower than D (children); \\
& C lower than B; \\
Progression & C HBeAg-positive lower than D HBeAg-negative \\
& B less likely than C; \\
HCC & A less likely than D \\
Mutations & C most likely; \\
& Pre-core mutant: A < C B < D; \\
& Core mutant: B < A D D C; \\
& Pre-S deletion: B less likely than C
\end{tabular}

$\mathrm{HCC}=$ hepatocellular carcinoma, $\mathrm{HBV}=$ hepatitis $\mathrm{B}$ virus, $\mathrm{HBeAg}=$ hepatitis $\mathrm{B}$ virus e antigen, $\mathrm{HBsAg}=$ hepatitis $B$ virus surface antigen.

Table 3 | Summary of virological and serological response rates to pegylated interferon alpha treatment regarding hepatitis B virus genotypes (71-77).

\begin{tabular}{lccc}
\hline & \multicolumn{3}{c}{ Response rate to PegIFN } \\
\cline { 2 - 4 } HBV & HBeAg-positive & HBeAg-negative & $\begin{array}{c}\text { Both } \\
\text { unspecified }\end{array}$ \\
A & CHB & CHB & - \\
B & $37-47 \%$ & $\sim 25-59 \%$ & $41 \%$ \\
C & $25-44 \%$ & $\sim 50 \%$ & $15 \%$ \\
D & $20-28 \%$ & $\sim 15-29 \%$ & - \\
E & $8-25 \%$ & - & $17.9-36 \%$ \\
F & - & - & $50 \%$ \\
G & - & - & $20 \%$ \\
H & - & - & $50 \%$ \\
\hline
\end{tabular}

PegIFN = pegylated interferon alpha, $\mathrm{CHB}=$ chronic hepatitis $\mathrm{B}, \mathrm{HBV}=$ hepatitis $B$ virus, $\mathrm{HBeAg}=$ hepatitis $B$ virus e antigen. 
Tran et al. reported that young females of childbearing age infected with genotype D had higher viral loads compared to those infected with other HBV genotypes (55). A similar conclusion was also drawn in our recent study in Slovenia (26). This finding is consistent with the natural course of HBV infection (56).

Some studies suggest that progression to cirrhosis is more common in patients infected with genotype $C$ compared to those infected with other HBV genotypes. Genotype B-infected persons are less likely to develop liver decompensation in comparison to those infected with genotypes A, C, and D (41). The clinical course of an infection with genotype $\mathrm{D}$ is more severe compared to one with genotype A (57).

A meta-analysis performed by Wong et al. showed that, compared to other HBV genotypes, the development of HCC is most frequent in genotype $\mathrm{C}$-infected persons (58).

Up until now no randomized controlled trials on the possible influence of HBV genotypes on the fulminant course of hepatitis B have been found. However, sporadic reports suggest that, among all HBV genotypes, genotype D was found most commonly related to a fulminant course of disease $(59,60)$.

A pre-core mutant of HBV does not produce HBeAg, resulting in HBeAg-negative CHB. The most frequent mutations include changes from guanine to adenine at base position 1896 (G1896A), and from cytosine to thymine at position 1858 (C1858T) in the pre-core region of the viral genome (61). Pre-core mutations are most commonly associated with HBV genotype D (65-75\%) and most rarely with HBV genotype A $(9-18 \%)(62,63)$. Pre-core mutations are found more often in genotype $\mathrm{C}$-infected persons than in those infected with genotype B (64). A national study in the United States found prevalences of pre-core mutations in $\mathrm{HBV}$ genotypes A, B, C and D of $3 \%, 46 \%, 24 \%$, and $73 \%$, respectively (47). A meta-analysis by Funk et al. showed very high prevalences of pre-core mutations regardless of HBV genotypes in some Mediterranean countries (Italy, Greece, Turkey, Israel, Bulgaria, and Spain) ranging from 67 to $100 \%$, whereas in Germany it ranged from 16 to $53 \%$ (65).

A prevalence of core promoter mutations was estimated only in Germany, being 59\% (65). Basal core promoter mutants cause a reduction in $\mathrm{HBeAg}$ production. Mutations include changes from adenine to thymine at base position 1762 (A1762T) and from guanine to adenine at position $1764(\mathrm{G} 1764 \mathrm{~A})$ in the basal core promoter region of the genome (61). The basal core promoter region and regulatory sequences play an important role in HBV replication and HBeAg formation. A clinical consequence related to core promoter mutations is a higher prevalence of HBeAg-negative $\mathrm{CHB}$, although some patients with core promoter mutations can be HBeAg-positive as well (66). They are mostly found in genotype C-infected persons (67). A national study from the United States found prevalences of core promoter mutations in HBV genotypes A, B, C and D of $41 \%, 27 \%, 60 \%$ and $42 \%$, respectively (40). Pre-S deletion is associated with faster progression of chronic disease and a higher risk of HCC, and it is more likely to be found in genotype $\mathrm{C}$ compared to genotype B-infected persons (68).

\section{Antiviral treatment and HBV genotypes}

By March 2018, eight drugs had been approved for the treatment of CHB, three nucleoside analogues (lamivudine, entecavir, and telbivudin), three nucleotide analogues (adefovir, tenofovir disoproxil, and tenofovir alafenamide), and standard/pegylated interferon alpha (IF; PegIFN) (69). The aims of antiviral treatment are suppression of HBV replication, permanent suppression of the viral load, seroconversion of HBeAg and HBV surface antigen (HB$\mathrm{sAg}$ ), normalization of aminotransferase levels, and a decrease in inflammation and fibrosis of the liver. Treatment has also been proven to prevent progression to cirrhosis and HCC (69). In 2017 the European Association for the Study of the Liver (EASL) published updated recommendations for CHB management and treatment mostly based on recent findings (69).

While a meta-analysis published in 2008 presented no difference in the nucleoside/nucleotide (NUC) treatment response among different HBV genotypes (70), other studies showed that response rates to treatment with PegIFN differ by HBV genotype and by HBeAg-status (71-77).

In HBeAg-positive CHB patients, pretreatment predictors of treatment response success are low HBV DNA viral load, high serum ALT levels (above two to five times the upper limit normal, ULN), HBV genotype, and high activity scores on liver biopsy. Genotypes A and B have been shown to be associated with higher rates of $\mathrm{HBeAg}$ seroconversion and $\mathrm{HBsAg}$ loss than genotypes $\mathrm{C}$ and D. In HBeAg-negative CHB patients, high baseline ALT, low baseline viral load, younger age, female sex, and HBV genotype were independent predictors of response to PegIFN therapy. Patients with genotypes $\mathrm{B}$ or $\mathrm{C}$ have a better chance of response than genotype D patients (69).

According to the latest EASL guidelines, PegIFN can be considered as an initial treatment option for patients with either HBeAg-positive or HBeAg-negative chronic infection. At week 12 of PegIFN treatment in HBeAg-positive CHB, HBsAg levels above $20,000 \mathrm{IU} / \mathrm{ml}$ for genotypes $\mathrm{B}$ and $\mathrm{C}$, or persistent HBsAg levels for genotypes A and D, are associated with a low HBeAg seroconversion rate, suggesting therapy should be stopped. HBsAg above $20,000 \mathrm{IU} / \mathrm{ml}$ persisting at week 24 in genotype A-D mean a low probability of HBeAg seroconversion, recommending stopping treatment as well. In HBeAg-negative persons infected with genotype D, a combination of no decrease in HBsAg levels and less than $\log 10 \mathrm{IU} / \mathrm{ml}$ reduction in viral load at week 12 predicts no response to the therapy, which should be stopped (69).

Janssen et al. reported up to a $47 \%$ response rate to PegIFN in HBeAg-positive genotype A-infected patients and $25 \%$ in genotype D-infected patients (71). Buster et al. suggest the use of PegIFN in all genotype A HBeAg-positive patients and in genotype $B$ and $C$ patients presenting with high ALT levels and low viral load (72). Response rates to PegINF in patients infected with genotypes E, F, G, and $\mathrm{H}$ have been shown to be poor $(73,74)$. A Taiwanese study showed that more patients infected with genotype B lost HBeAg after PegIFN treatment than those infected with genotype $C$ (75). Regardless of the HBeAg-status, the response rate to PegIFN therapy has been highest in genotype A (76), as well as leading to more stable remission (77).

\section{Conclusions}

Infection with a particular HBV genotype has several practical implications because it may influence the clinical outcome of the disease, as well as the outcome of antiviral treatment. A recent shift in the distribution of particular HBV genotypes in certain European countries as a consequence of large-scale migration flows and travel-related sexual transmissions may influence the choice of HBV treatment. Because the choice of antiviral drugs also depends on the HBV genotype, HBV genotyping before the introduction of antiviral treatment might be introduced for selected 
patient populations-for example, migrants and men with a history of high-risk sexual behavior. In Europe, studies have shown a predominance of genotype A in MSM in particular, in contrast to the general population, enabling treatment with PegIFN instead of NUCs.

\section{References}

1. Trepo C, Chan HLY, Lok A. Hepatitis B virus infection. Lancet. 2014;384:2053-63.

2. Lozano R, Naghavi M, Foreman K, Lim S, Shibuya K, Aboyans V, et al. Global and regional mortality from 235 causes of death for 20 age groups in 1990 and 2010: a systematic analysis for the Global Burden of Disease Study 2010. Lancet. 2012;380:2095-128.

3. World Health Organization. Global Viral Hepatitis Report 2017 [Internet]. [cited 2018 January 10]. Available from: http://apps.who.int/iris/bitstream/10665/ 255016/1/9789241565455-eng.pdf?ua=1.

4. ECDC Surveillance report. Annual Epidemiological Report for 2015. Hepatitis B [Internet]. [cited 2018 January 11]. Available from: https://ecdc.europa.eu/ sites/portal/files/documents/AER_for_2015-hepatitis-B.pdf.

5. Schweitzer A, Horn J, Mikolajczyc RT, Krause G, Ott JJ. Estimations of worldwide prevalence of chronic hepatitis $B$ virus infection: a systematic review of data published between 1965 and 2013. Lancet. 2015;386:1546-55.

6. McMahon BJ. The influence of hepatitis $B$ virus genotype and subgenotype on the natural history of chronic hepatitis B. Hepatol Int. 2009;3:334-42.

7. Kramvis A. Genotypes and genetic variability of hepatitis B virus. Intervirology. 2014;57:141-50.

8. Sunbul M. Hepatitis B virus genotypes: global distribution and clinical importance. World J Gastroenterol. 2014;20:5427-34.

9. Schaefer S. Hepatitis B virus genotypes in Europe. Hepatol Res. 2007;37:S20-26.

10. Zehender G, Shkjezi R, Ebranati E, Gabanelli E, Abazaj Z, Tanzi E, et al. Reconstruction of the epidemic history of hepatitis B virus genotype $D$ in Albania. Infect Genet Evol. 2012;12:291-8.

11. Ciccozzi M, Babakir-Mina M, Lo Presti A, Salpini R, Cella E, Gabanelli E, et al. Molecular analysis of hepatitis B virus in Bulgaria. J Med Virol. 2013;85:49-54.

12. Deterding K, Constantinescu I, Nedelcu FD, Gervain J, Nemeček V, Srtunecky O, et al. Prevalence of hepatitis B genotypes in central and eastern Europe. J Med Virol. 2008;80:1707-11.

13. Thibault V, Laperche S, Thiers V, Sayon S, Letort MJ, Delarocque-Astagneau E, et al. Epidemiology and clinical characteristics of hepatitis B identified through the French mandatory notification system. Plos One. 2013;8:e75267.

14. Moussa S, Brah S, Parola P, Gerolami R, Gamerre M, Boubli L, et al. Epidemiological, clinical, virological features of hepatitis B newly diagnosed in 2011 in Marseille University Hospitals, southeastern France. J Med Virol. 2016;88:828:36.

15. Sloan RD, Stranga AL, Ramsayb ME, Teoa CG. Genotyping of acute HBV isolates from England, 1997-2001. J ClinVirol. 2009;44:157-60.

16. Fylaktou A, Papaventsis D, Daoudaki M, Moskophidis M, Reiberger T, Malisiovas N. Molecular epidemiology of chronic hepatitis B virus infection in Greece. J Med Virol. 2011;83:245-52.

17. Mojiri A, Behzad-Behbahani A, Saberifirozi M, Ardabili M, Beheshti M, Rahsaz $M$, et al. Hepatitis B virus genotypes in southwest Iran: molecular, serological and clinical outcomes. World J Gastroenterol. 2008;14:1510-3.

18. Zuccaro O, Romano L, Mele A, Mariano A, Clementi M, Tosti ME, et al. Clinical, epidemiological and virological features of acute hepatitis B in Italy. Infection. 2015;43:431-41.

19. Vratnica Z, Zehender G, Ebranati E, Sorrentino C, Lai A, Vujošević D, et al. Hepatitis $B$ virus genotype and subgenotype prevalence and distribution in Montenegro. J Med Virol. 2015;87:807-13.

20. Ezzikouri S, Chemin I, Chafik A, Wakrim L, Nourlil J, Malki AE, et al. Genotype determination in Moroccan hepatitis B chronic carriers. Infect Genet Evol. 2008;8: 306-12.

21. Toy M, Veldhuijzen IK, Mostert MC, de Man RA, Richardus JH. Transmission routes of hepatitis $B$ virus infection in chronic hepatitis $B$ patients in the Netherlands. J Med Virol. 2008;80:399-404.

22. Bissinger A, Fehrle C, Werner CR, Lauer UM, Malek NP, Berg CP. Epidemiology and genotyping of patients with $\mathrm{HE}$ : genotype shifting observed in patients from central Europe. Pol J Microbiol. 2015;64:15-21.

23. Mota A, Guedes F, Areias J, Pinholl L, Fonseca Cardosol M. Epidemiological and genotypic profile of hepatitis B virus infection in northern Portugal. Rev Saude Publ. 2010;44:1-6.

24. Lazarević I, Čupic M, Delić D, Svirtlih SN, Simonović J, Jovanović T. Distribution of HBV genotypes, subgenotypes and HBsAg subtypes among chronically infected patients in Serbia. Arch Virol. 2007;152:2017-25.

25. Milosevic I, Delic D, Lazarevic I, Pavlovič IP, Korac M, Bojovic K, et al. The significance of hepatitis $B$ virus (HBV) genotypes for the disease and treatment outcome among patients with chronic hepatitis B in Serbia. J Clin Virol. 2013;58:54-8.

26. Kmet Lunaček N, Poljak M, Meglič-Volkar J, Rajter M, Prah J, Lesničar G, et al. Epidemiological, virological and clinical characteristics of hepatitis $B$ virus genotypes in chronically infected persons in Slovenia. Hepat Mon. 2017; 17:1-6.
27. Hirzel C, Wandeler G, Owczarek M, Gorgievski-Hrisoho M, Dufour JF, Semmo N, et al. Molecular epidemiology of hepatitis B virus infection in Switzerland: a retrospective cohort study. BMC Infect Dis. 2015;15:483-504.

28. Yacoubi L, Brichel S, Mansour W, Le Gal F, Hammami W, Sadaoui A, et al. Molecular epidemiology of hepatitis B and delta virus strains that spread in the Mediterranean north east coast of Tunisia. J Clin Virol. 2015;72:126-32.

29. Sunbul $M$, Leblebicioglu $H$. Distribution of hepatitis $B$ virus genotypes in patients with chronic hepatitis B in Turkey. World J Gastroenterol. 2005;11:1976-80.

30. Ciftci S, Keskin F, Badur S. Clinical features of hepatitis B virus genotypes in Turkish patients. J Pak Med Assoc. 2012;62:759-63.

31. Ozaras R, Balkan II, Yemisen M, Tabak F. Epidemiology of HBV sub-genotypes D. Clin Res Hepatol Gastroenterol. 2015;39:28-37.

32. Simmonds $P$, Midgley S. Recombination in the genesis and evolution of hepatitis B virus genotypes. J Virol. 2005;79:15467-76.

33. Valsamakis A. Molecular testing in the diagnosis and management of chronic hepatitis B. Clin Microbiol Rev. 2007;20:426-39.

34. Guirgis BSS, Abbas RO, Azzay HME. Hepatitis B virus genotyping: current methods and clinical implications. Int J Infect Dis. 2010;14:e941-53.

35. Hannoun C, Krogsgaard K, Horal P, Lindh M. Genotype mixtures of hepatitis B virus in patients treated with interferon. J Infect Dis. 2002;186:752-9.

36. van Houdt R, Bruisten SM, Geskus RB, Bakker M, Wolthers KC, Prins M, et al. Ongoing transmission of a single hepatitis $B$ virus strain among men having sex with men in Amsterdam. J Viral Hepat. 2010;17:108-14.

37. Rogstad KE. Sex, sun, sea, and STI: sexually transmitted infections acquired on holiday. BMJ. 2004;329:214-7.

38. Marschall T, Kretzschmar M, Mangen MJ, Schalm S. High impact of migration on the prevalence of chronic hepatitis B in the Netherlands. Eur J Gastroen Hepat. 2008;20:1214-25.

39. Congly SE, Wong P, Al-Busafi, Doucette SAK, Fung SK, Ghali P, et al. Characterization of hepatitis $B$ virus genotypes and quantitative hepatitis $B$ surface antigen titres in North American tertiary referral liver centres. Liver Int. 2013;33:1363-9.

40. Chu CJ, Hussain M, Lok AS. Hepatitis B virus genotype B is associated with earlier $\mathrm{HBeAg}$ seroconversion compared with hepatitis B virus genotype C. Gastroenterology. 2002;122:1756-62.

41. Orito E, Mizokami M, Sakugawa H, Michitaka K, Ishikawa K, Ichida T, et al. A case-control study for clinical and molecular biological differences between hepatitis B viruses of genotypes B and C. Japan HBV Genotype Research Group. Hepatology. 2001;33:218-23.

42. Yuen MF, Sablon E, Yuan HJ, Wong DK, Hui CK, Wong BC, et al. Significance of hepatitis $B$ genotype in acute exacerbation, $\mathrm{HBeAg}$ seroconversion, cirrhosis-related complications, and hepatocellular carcinoma. Hepatology. 2003;37:562-7.

43. Livingston SE, Simonetti JP, Bulkow LR, Homan CE, Snowball MM, Cagle HH, et al. Clearance of hepatitis $B$ e antigen in patients with chronic hepatitis $B$ and genotypes A, B, C, D, and F. Gastroenterology. 2007;133:1452-7.

44. Sánchez-Tapias JM, Costa J, Mas A, Bruguera M, Rodés J. Influence of hepatitis $B$ virus genotype on the long-term outcome of chronic hepatitis $B$ in western patients. Gastroenterology. 2002;123:1848-56.

45. Hadziyannis SJ. Natural history of chronic hepatitis B in Euro-Mediterranean and African countries. J Hepatol. 2011;55:183-91.

46. Hadziyannis JS, Vassilpoulos D. Hepatitis B e antigen negative chronic hepatitis B. Hepatology. 2001;4:617-20.

47. Chu CJ, Keeffe EB, Han SH, Perrillo RP, Min AD, Soldevila-Pico C, et al. Hepatitis $B$ virus genotypes in the United States: results of a nationwide study. Gastroenterology. 2003;125:444-51.

48. Kobayashi M, Arase Y, Ikeda K, Tsubota A, Suzuki Y, Saitoh S, et al. Clinical characteristics of patients infected with hepatitis B virus genotypes A, B, and C. J Gastroenterol. 2002; 37:35-9.

49. Kobayashi M, Arase Y, Ikeda K, Tsubota A, Suzuki Y, Hosaka T, et al. Clinical features of hepatitis B virus genotype A in Japanese patients. J Gastroenterol. 2003; 38:656-62.

50. Mayerat C, Mantegani A, Frei PC. Does hepatitis B virus (HBV) genotype influence the clinical outcome of HBV infection? J Viral Hepat. 1999;6:299-304.

51. Oommen PT, Wirth S, Wintermeyer P, Gerner P. Relationship between viral load and genotypes of hepatitis $B$ virus in children with chronic hepatitis B. J Pediatr Gastr Nutr. 2006;43:342-7.

52. Lindh M, Horal P, Dhillon AP, Norkrans G. Hepatitis B virus DNA levels, precore mutations, genotypes and histological activity in chronic hepatitis B. J Viral Hepat. 2000;7:258-67. 
53. Krarup H, Madsen P, Bentzen-Petersen A, et al. Higher levels of HBV-DNA in genotypes $B$ and $C$ compared to genotypes A and D. 59th Annual Meeting of the American Association for the Study of Liver Diseases (AASLD 2008). San Francisco. October 31 - November 4, 2008. Abstract 870.

54. Ni YH, Chang MH, Wang KJ, Hsu HY, Kao JH, Yeh SH, et al. Clinical relevance of hepatitis $\mathrm{B}$ virus genotype in children with chronic infection and hepatocellular carcinoma. Gastroenterology. 2004;127:1733-8.

55. Tran T, Gordon S, Fung S, Dinh P, Yee L, Martins EB, et al. Hepatitis B e antigen status and hepatitis B DNA levels in women of childbearing age with chronic hepatitis B infection screening for clinical trials. Plos One. 2015;10:e0121632.

56. Wu JF, Chang MH. Natural history of chronic hepatitis B virus infection from infancy to adult life-the mechanism of inflammation triggering and long-term impacts. J Biomed Sci. 2015;22:92-116.

57. Thakur V, Guptan RC, Kazim SN, Malhotra V, Sarin SK. Profile, spectrum and significance of HBV genotypes in chronic liver disease patients in the Indian subcontinent. J Gastroenterol Hepatol. 2002;17:165-70.

58. Wong GL, Chan HL, Yiu KK, Lai JW, Chan VK, Cheung KK, et al. Meta-analysis: the association of hepatitis $\mathrm{B}$ virus genotypes and hepatocellular carcinoma. Aliment Pharmacol Ther. 2013;37:517-26.

59. Garfein RS, Bower WA, Loney CM, Hutin YJ, Xia GL, Jawanda J, et al. Factors as sociated with fulminant liver failure during an outbreak among injection drug users with acute hepatitis B. Hepatology. 2004;40:865-73.

6o. Wai CT, Fontana RJ, Polson J, Hussain M, Shakil AO, Han SH, et al. Clinical outcome and virological characteristics of hepatitis B-related acute liver failure in the United States. J Viral Hepat. 2005;12:192-8.

61. Dienstag JL, Delemos AS. Viral Hepatitis. In: Mandell GL, Bennett JE, Dolin R, eds. Principles and practice of infectious diseases. 8th edition. Philadelphia: Elsevier Churchill Livingstone; 2015. p. 1439-68.

62. Rodriguez-Frias F, Buti M, Jardi R, Cotrina M, Viladomiu L, Esteban R, et al. Hepatitis $B$ virus infection: precore mutants and its relation to viral genotypes and core mutations. Hepatology. 1995;22:1641-7.

63. Hussain M, Chu CJ, Sablon E, Lok AS. Rapid and sensitive assays for determination of hepatitis $B$ virus (HBV) genotypes and detection of $\mathrm{HBV}$ precore and core promoter variants. J Clin Microbiol. 2003;41:3699-705.

64. Watanabe K, Takahashi T, Takahashi S, Okoshi S, Ichida T, Aoyagi Y. Comparative study of genotype $B$ and $C$ hepatitis $B$ virus-induced chronic hepatitis in relation to the basic core promoter and precore mutations. J Gastroenterol Hepatol. 2005;20:441-9.
65. Funk ML, Rosenberg DM, Lok ASF. World-wide epidemiology of HBeAg-negative chronic hepatitis $B$ and associated precore and core promoter variants. J Viral Hepat. 2002;9:52-61.

66. Kidd-Ljunggren K, Oberg M, Kidd AH. Hepatitis B virus X gene 1751 to 1764 mutations: implications for HBeAg status and disease. J Gen Virol. 1997;78:1469-78.

67. Yang HI, Yeh SH, Chen PJ, Iloje UH, Jen CL, Su J, et al. Associations between hepatitis $\mathrm{B}$ virus genotype and mutants and the risk of hepatocellular carcinoma. J Natl Cancer Inst. 2008;100:1134-43.

68. Lin CL, Liu CH, Chen W, Huang WL, Chen PJ, Lai MY, et al. Association of pre-S deletion mutant of hepatitis B virus with risk of hepatocellular carcinoma. J Gastroenterol Hepatol. 2007;22:1098-103.

69. European association for the study of the liver. EASL 2017 clinical practice guidelines on the management of hepatitis B virus infection. J Hepatol. 2017;67:37098.

70. Wiegand J, Hasenclever D, Tillmann HL. Should treatment of hepatitis B depend on hepatitis B virus genotypes? A hypothesis generated from an explorative analysis of published evidence. Antivir Ther. 2008;13:211-20.

71. Janssen HL, van Zonneveld M, Senturk H, Zeuzem S, Akarca US, Cakaloglu Y, et al. Pegylated interferon alfa- $2 \mathrm{~b}$ alone or in combination with lamivudine for $\mathrm{HBeAg}$. positive chronic hepatitis B: a randomised trial. Lancet. 2005;365:123-9.

72. Buster EH, Hansen BE, Lau GK, Piratvisuth T, Zeuzem S, Steyerberg EW, et al. Factors that predict response of patients with hepatitis $B$ e antigen-positive chronic hepatitis B to peginterferon-alfa. Gastroenterology. 2009;137:2002-9.

73. Boglione L, Cusato J, Cariti G, Di Perri G, D’Avolio A. The E genotype of hepatitis B: clinical and virological characteristics, and response to interferon. J Infect. 2014;69:81-7.

74. Erhardt A, Göbel T, Ludwig A, Lau GK, Marcellin P, van Bömmel F, et al. Response to antiviral treatment in patients infected with hepatitis $B$ virus genotypes $E-H$. J Med Virol. 2009;81:1716-20.

75. Kao JH, Wu NH, Chen PJ, Lai MY, Chen DS. Hepatitis B genotypes and the response to interferon therapy. J Hepatol. 2000;33:998-1002.

76. Erhardt A, Blondin D, Hauck K, Sagir A, Kohnle T, Heintges T, et al. Response to interferon alfa is hepatitis $B$ virus genotype dependent: genotype $A$ is more sensitive to interferon than genotype D. Gut. 2005;54:1009-13.

77. Buster EH, Flink HJ, Cakaloglu Y, Simon K, Trojan J, Tabak F, et al. Sustained $\mathrm{HBeAg}$ and HBsAg loss after long-term follow-up of HBeAg-positive patients treated with peginterferon alpha-2b. Gastroenterology. 2008;135:459-67. 